Short Communication

\title{
One-step removal of thallium (I) from groundwater by electrocoagulation using an aluminum anode
}

\author{
Wei Wang, Baogang Zhang* , Yunlong Li, Shuai Liang
}

School of Water Resources and Environment, MOE Key Laboratory of Groundwater Circulation and Environmental Evolution, China University of Geosciences (Beijing), Beijing 100083, P. R. China *E-mail: zbgcugb@gmail.com, baogangzhang@cugb.edu.cn

doi: $10.20964 / 2020.02 .31$

Received: 16 January 2018 / Accepted: 8 March 2018 / Published: 31 December 2019

Thallium (Tl) contamination in groundwater is a widespread issue, and the development of an efficient treatment process is of strong interest. We present, herein, a one-step Tl(I) removal method using electrocoagulation systems. Using this method, $86.4 \% \pm 1.0 \%$ of total $\mathrm{Tl}$ was removed within $60 \mathrm{~min}$ by an aluminum anode, with an initial $\mathrm{Tl}(\mathrm{I})$ concentration of $10 \mathrm{mg} / \mathrm{L}$ and current density of 10 $\mathrm{mA} / \mathrm{cm}^{2}$. The $\mathrm{Tl}$ removal efficiency increased with increasing current density. However, Tl removal efficiency increased first and then decreased with increasing $\mathrm{pH}$ in alkaline $\mathrm{pH}$ range. $\mathrm{Tl}(\mathrm{I})$ was partly oxidized to $\mathrm{Tl}$ (III) and both species precipitated with function of synchronously produced coagulants. $\mathrm{X}$-ray photoelectron spectroscopy was used to analyze the recovered precipitate as well as to confirm the generation of $\mathrm{Tl}(\mathrm{III})$ and simultaneous adsorption of $\mathrm{Tl}(\mathrm{I})$. This study provides an efficient alternative for one-step $\mathrm{Tl}$ removal from groundwater via electrocoagulation.

Keywords: Thallium; Electrocoagulation; Aluminum anode; Groundwater

\section{FULL TEXT}

(C) 2020 The Authors. Published by ESG (www.electrochemsci.org). This article is an open access article distributed under the terms and conditions of the Creative Commons Attribution license (http://creativecommons.org/licenses/by/4.0/). 